Mr. Hoover easily obtained swings of twenty millimetres, which is equivalent to a twentyfold preciseness in his measurements.

Far-reaching results may be attained with the new technique. A means is now at hand of determining with considerable accuracy temperatures, depths and compositions of the atmospheres of stars, and this will make possible more accurate estimates of the size and nature of stellar bodies.

\section{Economics of Industry}

A RISING out of the Conference held in 1937 by the International Industrial Relations Institute, when the theme was productivity and standards of living as influenced by industrial relations, the Institute has arranged a series of publications, the I.R.I. Social Economic Series, to present the results of its studies. Two of these have now appeared, the first by A. Carrillo on "Mexico's Resources for Livelihood" including a general introduction to the series on the world's natural resources and standards of living (Mexico's Resources for Livelihood : a Study of the Influence of Foreign Ownership. By Alejandro Carrillo. Pp. 34. The Hague and New York: International Industrial Relations Inst., 1938. 25 cents).

This introduction outlines the field opened up, including an analysis of the distribution of the world's raw materials and a survey of the hitherto abortive efforts to deal with the problem through international action. The implications of power production for economic organization are also considered, and in addition to summaries of the main arguments in the papers submitted to the 1937 Conference a number of suggestions for immediate action are outlined. Mr. Carrillo's special study gains further interest in view of the expropriation of oil by the Mexican Government since the paper was written, and it facilitates appreciation of the situation in Mexico and the important moral achievements of the revolution.

The second paper, by M. Yergan on gold and poverty in South Africa, is a study of economic organization and standards of living; it is yet another indictment of the labour policy pursued in South Africa with its deliberate exploitation of native labour as part of the natural resources of the country (Gold and Poverty in South Africa: a Study of Economic Organisation and Standards of Living. By Max Yergan. Pp. 24. The Hague and New York: Intemational Industrial Relations Inst., 1938. 15 cents). The importance of workers' living standards as an element in the problem of raw materials is again emphasized, and while the report recognizes that the errors and dangers of the policy hitherto pursued are now perceived by an increasing body of European opinion, the material it presents overthrows a conception of trusteeship under the conditions which prevail in South Africa. The importance of encouraging and co-operating with all those in South Africa, whether African or European, who are aware of the dangers and real needs, and striving to meet them, is emphasized, as well as the need for strenuous efforts to eradicate the hates and prejudices which repression and exploitation have developed within the ranks of both Africans and Europeans.

\section{Science News a Century Ago}

Temperature of the Crust of the Earth

WITH the assistance of the British Association, J. D. Forbes in 1837-38 made determinations of the temperature of the soil in the neighbourhood of Edinburgh, the results of his experiments being given in a paper read to the Royal Society of Edinburgh on December 3, 1838, entitled "Discussion of One Year's Observations of Thermometers sunk to different Depths in different localities in the Neighbourhood of Edinburgh".

The principal purpose of the experiments undertaken by Forbes was to ascertain the progress of solar heat in the crust of the earth, and had no immediate reference to the question of central heat. With the view of rendering the observations comparable with those at Paris and Brussels, the lowest thermometers had their bulbs 24 French feet ( $=25 \cdot 6$ English) below the surface. Other thermometers were placed at depths of 12, 6 and 3 French feet. The observations were begun in February 1837 and were continued weekly.

The three stations for the experiments were at the Observatory, Calton Hill, in the sand in the Experimental Garden and in the compact coal formation sandstone of Craigleith Quarry. Among other results obtained, Forbes found that at the greatest depths the annual range temperature was $1 \cdot 45^{\circ} \mathrm{F}$. at the Observatory, $2 \cdot 1^{\circ} \mathrm{F}$. at the Garden and $4 \cdot 1^{\circ} \mathrm{F}$. at the Quarry.

\section{Footprints of the Chirotherium}

AT a meeting of the Geological Society on December 5,1838 , one of the communications was "An Account of the Footsteps of the Chirotherium and five or six other unknown animals lately discovered in the quarries of Storeton Hill, between the Mersey and the Dee". The communication was made by the Natural History Society of Liverpool and was accompanied by drawings by J. Cunningham. In 1834 there were discovered in several quarries at the village of Hessburg near Hildberghausen, casts in a grey quartzose sandstone, resembling to some extent a human hand, and for which Prof. J. J. Kaup proposed the provisional name of Chirotherium. In June 1838, similar casts were discovered in the Storeton Hill quarries. The Natural History Society of Liverpool appointed a committee to report on these.

The red sandstone of the peninsula of Wirral may be divided into three layers : a lower consisting of a red or variegated sandstone and conglomerate, a middle of white and yellow sandstone, and an upper or red or variegated marl and sandstone containing pebbles of quartz. It is the middle division which was worked at the quarry. The strata there are of unequal thickness, and are separated by thin seams of whitish clay. The casts appear to have been moulded in impressions made by the Chirotherium and other animals walking over the clay.

The animal had been tracked by its marks $16 \mathrm{ft}$. on one stone. Although the footsteps of the Chirotherium are the most prominent there are slabs covered by raised casts apparently made by tortoises and saurian reptiles. 